\title{
TRANSFORMASI NILAI RUKUN ISLAM DALAM PENINGKATAN SUMBER DAYA INSANI (SDI) BERPERADABAN
}

\author{
M.Samson Fajar \\ Universitas Muhammadiyah Metro \\ Jalan Ki Hajar Dewantara 15 A Kota Metro \\ ibnuummi@gmail.com
}

\begin{abstract}
ABSTRAK
Islam as a true religion and universal. Islam is also a religion that includes rituals and spiritual values. The pillars of Islam must be understood as a value of ritual as well as spiritual, which must transform values into life, especially in the form of civilized human resources. The Tranformation process is carried out through a gradual process (tadarruj) of all the values embedded in its life. With this process, it will form a superior features of civilization Human resources with personal and social competencies

Pillars of Islam as a strategy of forming superior quality of Human Resource, is making it as a gradual system in shaping of human Resource. The phasing begins with the formation of beliefs, character formation, financial formation, the formation of social sensitivity and the formation of internationally qualified individuals.

Pillars of Islam as an Human Resource profile capable of global competitiveness should make it as a competency in building personal coopency and social and organizational competence. Personal competence includes the ability to build vision statements, change personality, and self-control in order to achieve success. While the social and organizational competence, including kemamapuan menysinergikan and potency in self and ummah to build strength, and ability to develop themselves continuously. Key Words: Transformation, human resources, the pillars of islam.
\end{abstract}




\section{A. PENDAhuluaN}

Nilai Islam sebagai nilai universal (kaffah) adalah sebuah nilai yang mencakup nilai pengetahuan (ma'rifah), nilai tujuan (haqiqah) dan nilai aksi (thariqah) ${ }^{1}$. Nilai Islam juga nilai yang terpadu antara iman, ilmu dan amal. Inilah yang disebut sebagai agama yang telah sempurna. Sebagaimana Allah swt berfirman:

Artinya:"....... pada hari ini telah Kusempurnakan untuk kamu agamamu, dan telah Ku-cukupkan kepadamu nikmat-Ku, dan telah Kuridhai Islam itu Jadi agama bagimu. ....(al- Maidah ayat 3)

Kesempurnaan Islam menjadikan agama ini menjadi agama yang terakhir dan tidak ada agama yang secara sistem telah sempurna, dan secara teologis telah sesuai dengan nilai tauhid, fitrah dan akal manusia. Sehingga Islam adalah agama yang bukan hanya difahami secara formalistik akan tetapi juga bernilai subtantif dan aplikatif. ${ }^{2}$

Dalam konteks peningkatan sumberdaya manusia, nilai Islam harus menjadi sumber dalam pembentukan SDI berperadaban unggul dan berkarakter. Nilai Islam harus ditransformasikan menjadi sebuah sistem pembentukan SDI yang memiliki identitas mandiri dan memiliki excelensi serta distingsi dibandingkan dengan SDI yang terbentuk dari nilai-nilai filsafat positifistik dan menejemen konvensional.

Krisis terbesar saat ini adalah krisis nilai kebenaran. Krisis ini lebih dahsyat dibandingkan dengan krisis energi, krisis pangan, kesehatan, transportasi dan air. Karena dengan hilangnya nilai kebenaran hakiki dalam diri manusia sebagai subjek peradaban maka krisis energi, pangan, kesehatan, transportasi dan air akan lebih parah. Karena manusia akan berbuat sesuai dengan nafsunya dan tidak terkendali oleh kebenaran yang ada dalam hati dan hukum Allah SWT.

Indonesia dengan berbagai permasalahanya membutuhkan SDI yang berkualitas, unggul dan berkarakter. Karena bangsa Indonesia mengalami kondisi yang akut selama beberapa dekade ini. Masalah politik terjadi krisis pemimpin yang adil dan bejaksana, dalam masalah ekonomi bangsa ini terjangkit

1 Toto Tasmara, Membudayakan Etos Kerja Islami (Jakarta: Gema Insani Press, 2004), h. 6.

2 Yusuf Al Qaradhawi, Kebangkitan Gerakan islam Dari Masa Transisi menuju kemenangan (Pustaka Al Kautsar, 2003), h. 4. 
kapitalisme yang melemahkan ekonomi ummat, dalam masalah pendidikan terjangkit sistem sekulerisme, serta dalam masalah budaya bangsa ini terjangkit hedonisme. Pada akhirnya semua itu melemahkan SDI yang akan mampu bersaing dan berbuat untuk membangun bangsa ini menjadi bangsa yang mampu berkiprah di dunia serta memberikan manfaat kepada seluruh alam (rahmatan lil 'alamini).

Krisis kebenaran tersebut disebabkan bangsa ini tidak berpegang pada nilai kebenaran mutlak yang diakui oleh seluruh ilmuwan, yaitu nilai wahyu (Islam). Sehingga tidak ada jalan lain dalam meningkatkan SDI berperadaban, unggul dan berkarakter harus mentransformasikan nilai-nilai Islam ke dalam sistem pembentukan SDI. Sehingga nilai Islam hidup dalam kehidupan manusia, bukan hanya menjadi wacana dan konsep melangit yang tidak turun ke dalam kehidupan manusia.

Dalam penelitian ini akan dibahas bagaimana nilai-nilai Islam dapat ditransformasikan dalam peningkatan SDI berperadaban, unggul dan berkarakter. Pertanyaan tersebut akan dibahas dengan pola pendekatan Prosedur inferensi tekstual. Prosedur inferensi tekstual ini dimaksudkan untuk menderivasi aturan-aturan dan konsep-konsep dari wahyu secara sistematis dan memadai. Ada empat langkah yang harus dilewati dalam prosedur ini, yaitu:

1. Mengindentifikasi teks (al-Qur'an dan Sunnah) yang relevan dengan persoalan yang sedang dibahas. Tetapi identifikasi ini tidak semata-mata inventarisasi, tetapi mencakup pula analisis dan pendalaman linguistik secara tematis.

2. Memahami (menafsirkan) makna pernyataan teks secara memadai dan relevan baik secara individual (leksikal) maupun dalam kaitanya dengan yang lain (secara kontekstual).

3. Menjelaskan ( $\left.t a^{\prime} l i l\right)$ terhadap teks, yaitu mengidentifikasi causa efisien ('illah) yang menjadi dasar adanya perintah atau petunjuk dalam teks. Ini bertujuan mengindentifikasi sifat umum yang dimiliki oleh benda yang berbeda-beda yang menjustifikasi acuan pengunaan term yang sama sebagai langkah awal menemukan prinsip-prinsip universal yang mengatur berbagai pernyataan syari'ah. 
4. Membangun suatu aturan dan konsep umum yang diderivasi dari teks. Ini dapat dicapai dengan proses abstraksi terus-menerus, sehingga aturan/konsep hasil derivasi dari teks itu dapat dimasukkan ke dalam aturan lain yang memiliki tingkat abstraksi lebih tinggi. ${ }^{3}$

Secara sederhana dapat digambarkan dalam ragaan di bawah ini:

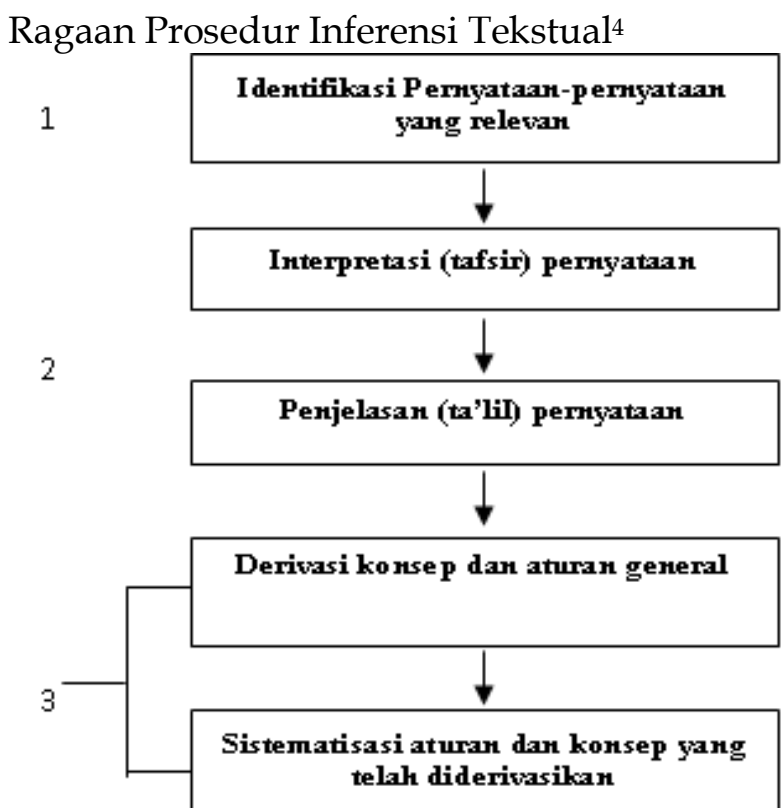

Sebelumnya harus disadari bahwa bagaimanapun canggihnya sistem aturan dan konsep yang berhasil diderivasikan dari wahyu, hal itu tidak cukup memadai untuk mendasari perbuatan/tindakan tertentu, karena dua alasan. Pertama, sistem itu sendiri terdiri dari aturan general dan universal, aplikasinya terhadap kasus partikular membutuhkan pertimbangan dan spesifkasi lebih lanjut. Hal ini dapat dilakukan dengan memasukkan informasi tentang watak aksi dan interaksi

${ }^{3}$ Muhammad Anas az-Zarqa, "Tahqiq Islamiyah "Ilm al-Iqtisad: alManhaj wa al-Mafh-m," dalam Toward Islamization of Disciplin," vol. Muhammad Anas az-Zarqa (Herdon: IIIT, n.d.),h. 182-85. 
individual atau kolektif. Kedua, aplikasi aturan universal mensyaratkan pengetahuan tentang syarat-syarat yang ada.

Dengan pendekatan tersebut diharapkan akan memunculkan sebuah rumusan sistem pengembangan SDI yang terbentuk dari transformasi nilai-nilai Islam sebagai perintah wahyu dalam al-Qur'an dan al-Sunnah. Sehingga sistem tersebut akan mampu di aplikasikan sebagai syari' ah bagi ummat manusia dalam peningkatan kualitas SDI unggul dan berkarakter.

\section{B. PROSES TRANSFORMASI NILAI RUKUN ISLAM DALAM PEMBENTUKAN SDI}

Proses perubahan sosial yang terjadi pada konteks tertentu terdiri dari proses reproduksi dan proses transformasi ${ }^{5}$ Dimana proses reproduksi merupakan proses mengulang, menghasilkan kembali segala sesuatu yang menjadi warisan budaya yang terdiri dari warisan material (kebendaan, teknologi) dan warisan immaterial (adat, norma, dan nilai).

Sedangkan proses transformasi adalah suatu proses penciptaan hal baru yang dihasilkan oleh ilmu pengetahuan dan teknologi yang mampu mengubah aspek budaya yang sifatnya material saja dan tidak mengubah aspek budaya yang sifatnya immaterial. Sehingga dapat dikatakan bahwa suatu proses transformasi tidak mampu mengubah nilai-nilai, norma, dan adat yang ada dalam suatu masyarakat dalam proses perubahan sosial.

Perubahan sosial juga mendapat perhatian dalam agama Islam. Jalaludin Rakhmat menyatakan bahwa terdapat dua hal penting dalam proses perubahan sosial menurut Islam; Pertama, Islam memandang perubahan sosial harus dimulai dari perubahan individu. Kedua, secara berangsur-angsur, perubahan individu ini harus disusul dengan perubahan institusional. Dari dua hal tersebut, perubahan sosial yang dimaksud dalam Islam adalah perubahan dalam hal struktur sosial yang timpang, hegemonik, dan dominatif. Oleh karena itu, perubahan struktur sosial yang ada merupakan syarat

${ }^{5}$ Agus Salim, Perubahan Sosial; Sketsa Teori dan Refleksi Metodologi Kasus Indonesia (Yogyakarta: Tiara Wacana, 2002), h. 20-21. 
yang harus ada untuk mencapai suatu bentuk ideal. Sehingga perubahan sosial tersebut tergantung pada struktur-struktur kekuasaan dalam masyarakat pada bidang politik, ekonomi, sosial, budaya, dan ideologi ${ }^{6}$

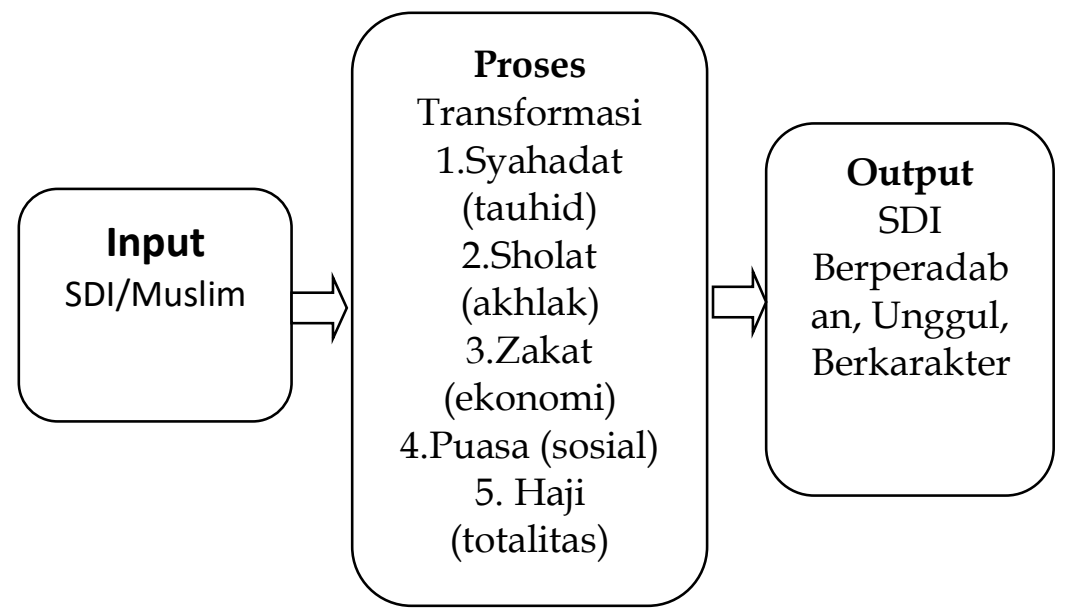

Menggunakan teori Jalaludin di atas maka nilai Rukun Islam dapat ditransformasikan berawal dari individu kemudian menuju pada institusi. Input SDI dalam bentuk awalnya melakukan proses tarnsformasi dengan nilai-nilai rukun Islam di atas, pada akhirnya nilai-nilai tersebut akan terinternalisasi dalam diri mereka, sehingga akan menjadi pribadi yang baik.

\section{STRATEGI PENINGKATAN SDI BERPERADABAN, UNGGUL DAN BERKARAKTER ISLAMI}

Strategi dalam meningkatkan SDI berperadaban, unggul dan berkarakter adalah dengan melakukan proses internaslisasi nilai-nilai Islam tersebut dalam pendidikan. Dalam pendidikan modern ini terdapat dua pola 122 iran yang kadang sulit dipertemukan, sebab diantara kcuuu pola tersebut terdapat masalah perbedaan yang fundamental.

Yang pertama; Pendidikan diartikan sebagai upaya fasilitatif untuk menciptakan situasi atau lingkungan di mana

${ }^{6} \mathrm{http}: / /$ rorophei.blogspot.co.id/2013/07/islam-dan-perubahansosial_24.html 
potensi dasar yang dimiliki peserta didik dapat dikembangkan sesuai tuntutan kebutuhan mereka, agar dapat survive menghadapi tantangan zaman di mana mereka hidup. Titik berat pendidikan ini adalah perubahan dan perbaikan untuk masa depan, yang antara lain harus dikejar dengan mentransfer pengetahuan dan ketrampilan sebanyak mungkin, dan penguasaan metoda-metoda yang memungkinkan para peserta didik beradaptasi dengan lingkunganya. ${ }^{7}$

Yang Kedua, Pendidikan diartikan sebagai proses pewarisan dan pelestarian nilai-nilai (converses of human value) dan sosialisasi perilaku anak yang sudah menjadi model anutan masyarakat lingkungan peserta didik, dan yang sudah diterima kebenaranya secara baku. Maka pewarisan nilai-nilai luhur kepada peserta didik menjadi masalah sentral.

Strategi pendidikan Islam yang ditawarkan dalam rangka mentransformasikan nilai-nilai Islam tersebut adalah:

1. Melakukan transfer nilai-nilai Islam dalam rangka mempertebal keimanan, memelihara ketaatan ibadah dan mengembangkan akhlakul karimah, di mana program kurikulumnya dikembangkan dengan pendekatan etis dan memberikan output manusiamanusia mumin, muslim yang sholih secara individual dan sosial.

2. Menguatkan kemampuan metodologis kepada peserta didik untuk memahami pesan-pesan dasar agama Islam, dan memberikan motivasi yang memungkinkan mereka mengembangkan pemahaman agamanya yang kondusif dengan zamanya.

3. Mengintegrasikan nilai-nilai Islam dengan problematikan empiris, sehingga peserta didik akan memiliki kejelian terhadap lingkunganya berdasarkan pemahaman teologi yang didapat dari preskripsi normatif.

7 Muhammad Tolchah Hasan, Islam dan Masalah Sumber Daya Manusia (Jakarta: Lantabora Press, 2003), h. 199. 
4. Mendialogkan subtansi ajaran agama dengan materi agama, sehingga peserta didik memperoleh kesempatan berpartisipasi dalam memahami persoalan dan mempersepsi ajaran-ajaran agama yang dikajinya.

5. Mendorong dan mengembangkan potensi spiritualitas peserta didik, sehingga membentuknya sebagai kekuatan rohani yang mengfilter ragam keserakahan materialistis dan konsumeris dalam kehidupan modern yang penuh rayuan duniawi. ${ }^{8}$

Dengan strategi di atas maka nilai rukun Islam akan menjadi sebuah tahapan dalam pembentukan SDI yang berkualitas. Pendidikan menjadikan rukun Islam sebagai nilai yang diintegrasikan, didialogkan dan diinternalisasikan dalam kepribadian mereka, dengan pola pentahapan yang gradual (tadarruj). Proses pentahapan ini sesuai dengan konsep pembentukan masyarakat muslim pada era turunya al-Qur'an yang berangsur-angsur sesuai dengan kebutuhan, kondisi dan keadaan masyarakat saat itu.

Menurut teori ini, suatu pembelajaran dianggap efektif apabila dilakukan secara berangsur-angsur, step by step, dan sedikit demi sedikit. 9 Teori ini didasarkan pada kemampuan manusia yang terbatas. Kesemuanva dapat dicapai dengan kebertahapan kerja akal, dan m 24 akan sesuatu yang lazim apabila belajar juga harus mengikuti proses kerja akal secara bertahap. Prinsip ini tidak lain juga dapat membantu peserta didik untuk menguasai suatu pengetahuan.

Pembelajaran melalui teori tadarruj membawa dampak pada kesanggupan peserta didik akan tumbuh kembang pengetahuannya sedikit demi sedikit melalui pengulanganpengulangan dan pembiasaan terhadap pengetahuan yang dipelajari. Suatu proses belajar akan efektif melalui pengulangan dan pembiasaan.

Oleh sebab itu aplikasi tadarruj dalam nilai-nilai rukun Islam ada lima tahap diantaranya adalah :

a. Pembentukan keyakinan (belief building) tauhid yang kuat.

8 Ibid, 204-205

9 Fathiyyah Hasan Sulaiman, Pandangan Ibnu Khaldun Tentang Ilmu dan Pendidikan (Bandung: CV. Diponegoro, 1987), h. 61. 
b. Pembentukan Karakter (chararcter building)

c. Pembentukan kemampuan financial dan kesejahteraan (finacial and welfare building)

d. Pembentukan ketangguhan dan jiwa sosial (survive and social building).

e. Pembentukan pribadi berkualitas internasional dan totalitas (internasionalization and totality building).

\section{PROFIL SDI BERDAYA SAING GLOBAL}

Etos kerja pribadi muslim, harus mampu mewujudan isyarat atau ayat al-Qur'an sebagai sumber inspirasi dan motivasi besar untuk berinteraksi, bahkan bersaing dalam format atau sekala global dengan tujuan atau tema sentral rahmatan lil'alamin ${ }^{10}$. Pergaulan global ini diterangkan dalam al_Qur'an:

Artinya:" Hai manusia, Sesungguhnya Kami menciptakan kamu dari seorang laki-laki dan seorang perempuan dan menjadikan kamu berbangsa - bangsa dan bersuku-suku supaya kamu saling kenal-mengenal. Sesungguhnya orang yang paling mulia diantara kamu disisi Allah ialah orang yang paling taqwa diantara kamu. Sesungguhnya Allah Maha mengetahui lagi Maha Mengenal.(al-Hujurat ayat 13)

Dalam ayat ini, Allah SWT memberikan sinyal bahwa interaksi manusia harus secara global, dan yang palingg unggul adalah yang paling bertaqwa. Ketaqwaan SDI adalah ketika mereka mengaplikasi seluruh nilai Islam secara totalitas, sehingga melahirkan copetensi yang unggul. Ada dua kopetensi yang hendaknya dimiliki oleh SDI dalam persaingan global, sebagai spirit rukun Islam:

10 Tasmara, Membudayakan Etos Kerja Islami, h. 151-152. 


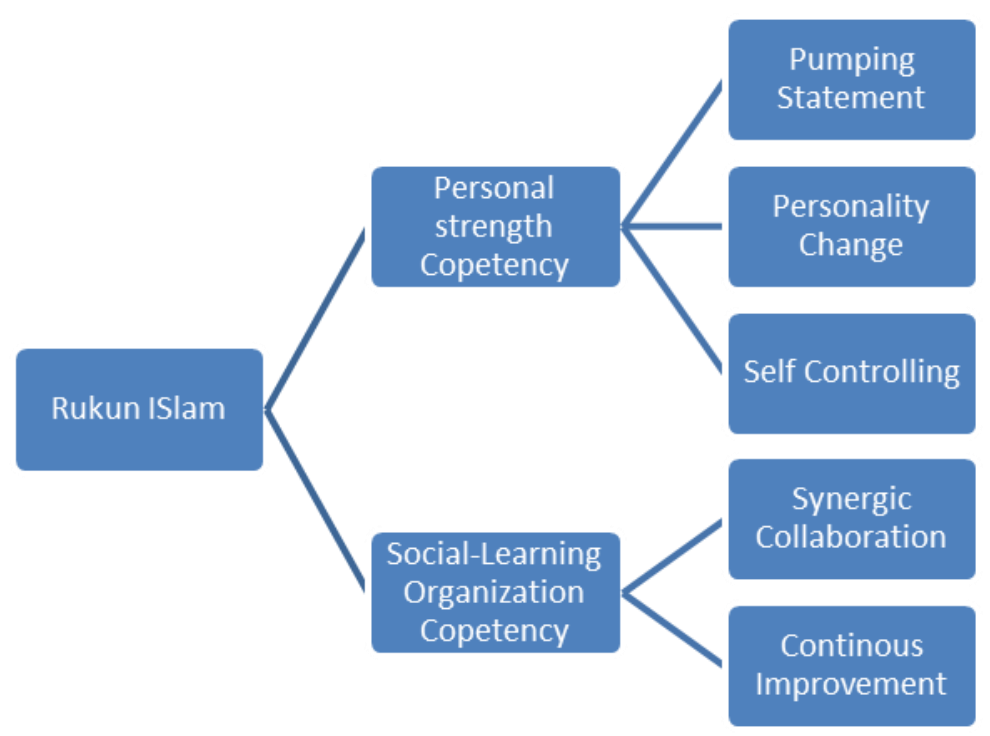

Yang pertama, Personal Strength copetency,adalah kopetensi personal seorang muslim untuk melakukan perubahan diri dan aksi nyata dalam kehidupan. Perubahan dan aksi nyata dalam kopensi pertama ini adalah:

a. Pumping Statement (Syahadat): yaitu pernyataan secara pribadi sebagai komitem untuk melakukan perubahan diri menuju sukses. Hal ini meliputi vision, motivation, leadership, knowledge, menegement dan exercise vang tidak bertentangan dengan prinsip keimanan. 28 cang muslim harus memiliki statemen dalam memban, gu. srbit suksesnya.

b. Personality Change copentency (sholat); merupakan perubahan fisik terhadap prilaku sehari-hari. Perubahan prilaku terbaik adalah dengan menjadi potret diri master dan gaya multisensori. Dengan perubahan fisik harian ini akan membentuk habbit yang baik, yang akan mengantarkan menjadi pribadi efektif dan profesional dalam mencapai visi hidupnya.

c. Self Controlling (puasa): merupakan perubahan fisik, mental dan emosi untuk mengendalikan emosi, amarah dan mengurangi sikap under confidence pada diri seseorang. Self controlling akan menjadi penjaga dari sikap berlebihan atau sikap yang akan mengeluarkan energi negatif pada orbit sukses manusia. 
Yang kedua : Social-Learning Organization Copetency, adalah merupakan kopetensi untuk melakukan tindakan nyata aksi perubahan terhadap pembinaan hubungan dunia sosial (interpersonal) dan bagian penting dari proses organisasi pembelajaran. Ada dua bentuk tindakan nyata pada kopetensi ini:

a. Syinergic colaboration (zakat), merupakan aksi perubahan secara fisik, mental, emosi dalam membangun jaringan dan kolaborasi aktifitas menuju jalur sukses. Kemampuan mengsinergikan dan mengkolaborasikan kekuatan adalah unsur sangat penting dalam kehidupan global, karena individualis hanya akan melemahkan kehidupan ummat. Jiwa membantu dan mengsinergikan potensi bersama adalah kekuatan terbesar untu sebuah peradaban.

b. Continous improvement (haji): merupakan aksi perubahan kendali dari puncak sukses manusia yang kembali memposisikan diri sebagai individu yang penuh dengan kekuarangan dan karenanya perlu memperbaiki diri secara terus menerus. Hal ini dapat dilihat dalam ritual wukuf di arafah, mereka menyadari akan segala kekurangan dan dosanya, kemudian bertaubat dan memperbaiki diri terus menerus. ${ }^{11}$

\section{E. KESIMPULAN}

Adapun kesimpulan dari penelitian ini adalah:

1. Rukun Islam adalah bukan hanya suatu ritual formal, akan tetapi mengandung spirit nilai-nilai prinsipel Islam yang harus ditransformasikan dalam kehidupan manusia, secara spesifik dalam membentuk SDI berkualitas. Adapun nilainilai prinsip rukun islam tersebut adalah, tauhid, akhlak, kesejahteraan sosial, control sosial dan nilai totalitas.

2. Rukun Islam sebagai strategi pembentukan SDI unggul berkualitas, adalah menjadikannya sebagai sebuah sistem yang bertahap dalam membentuk SDI. Pentahapan tersebut berawal dari pembentukan keyakinan,

11 Tengku Tuan Ramli, Pumping Power (Bekasi: Pustaka Inti, 2007), h. 153-154. 
pembentukan karakter, pembentuk financial, pembentukan kepekaan sosial dan pembentukan pribadi berkualifikasi internasional.

3. Rukun Islam sebagai sebuah profil SDI yang mampu berdaya saing global hendaknya menjadikanya sebagai kopetensi dalam membangun kopetensi personal dan kopetensi social dan organisasi. Kopetensi personal meliputi kemampuan membangun statemen visi, melakuan perubahan kepribadian, kemampuan mengontrol diri dalam meraih kesuksesan. Sedangkan kopetensi sosial dan organisasi, meliputi kemamapuan mengsinergikan dan mengkolaborasikan segala potensi dalam diri dan ummat untuk membangun kekuatan, serta kemampuan mengembangkan diri secara terus menerus (kontinyu).

\section{DAFTAR PUSTAKA}

Hasan, Muhammad Tolchah. Islam dan Masalah Sumber Daya Manusia. Jakarta: Lantabora Press, 2003.

Qaradhawi, Yusuf Al. Kebangkitan Gerakan islam Dari Masa Transisi menuju kemenangan. Pustaka Al Kautsar, 2003.

Ramli, Tengku Tuan. Pumping Power. Bekasi: Pustaka Inti, 2007.

Salim, Agus. Perubahan Sosial; Sketsa Teori dan Refleksi Metodologi Kasus Indonesia. Yogyakarta: Tiara Wacana, 2002.

Sulaiman, Fathiyyah Hasan. Pandangan Ibnu Khaldun Tentang Ilmu dan Pendidikan. Bandung: CV. Diponegoro, 1987.

Tasmara, Toto. Membudayakan Etos Kerja Islami. Jakarta: Gema Insani Press, 2004.

Zarqa, Muhammad Anas az-. "Tahqiq Islamiyah "Ilm al-Iqtisad: alManhaj wa al-Mafh-m," dalam Toward Islamization of Disciplin." Vol. Muhammad Anas az-Zarqa. Herdon: IIIT, n.d. 